agencies of business and of government. We will possess all and more than Longfellow ever had.

It is not possible to handle these materials and not increase our interest in the time prior to 1847 ; it is not possible thus to become more sensitive to the relations of Indian and white man and remain oblivious to the influence of William Clark. Our collections as they approach completeness will form a merited and adequate memorial to William Clark.

\title{
LAST FIGURE OF THE SPIRIT LAKE TRAGEDY
}

At the time and place where civilization has come into contact with savagery, suffering and sacrifice have seemed to us ennobled. Wherever types of life have differed, as our race came up, the adjustments of type against type, have had results comparable with the adjustments which geology explains through slips and faults as causes of earth tremors. With differing ideals, motives; and traditions among the types and races of mankind, both these phenomena appear elements of creation itself.

As the wrinkled face of weathered earth was smoothed by glaciers whose paths were weathered down and smoothed again, so race tore over and through other races. But it has been one of the mercies to mankind that wars have often left with both victor and vanquished the best that either brought into the field of conflict.

As the Caucasian lobe of humanity advanced across the Mississippi Valley it met, melted and absorbed obstruction and was met, bruised and shredded in the process. At the sanguine, sutured edge, as it worked westward, one cannot tell the Indian's from the white man's blood. In what is now Iowa, Minnesota, and the Dakotas, the last impediment was the nation of the Sioux, its bands and braves. That great, vigorous, aboriginal family of man came up through Revolutionary times allies of the British and trade subjects of the British fur companies. Their southern borderlands were the same as the northern borderlands of allies of the French and trade subjects of the French fur companies. No line or zone separating the great masses was marked or fixed. The serrated fracture varied with the varying pressure and resist- 
ance which changed with the changing forces of European politics, commerce and religious zeal applied through their media against the contact surfaces.

The Sioux then for more than a century constantly suffered or expected trouble. There was no buffer state like Belgium. When Ilinois, after the Revolution, and Iowa, after the Louisiana purchase, with red and white inhabitants, passed under the stars and stripes, the feuds and enmities passed with them. The very vitals of the Sioux country pressed against the Sac and Fox regions, and the Sac and Fox, so imperceptibly yielding to Caucasian forces, left this Caucasian floe to tear and be torn by, to run over or be submerged by, the opposing Sioux mass. Friction and pressure and murder and rapine on the Iowa prairie was like the lurid light in America upon a historic canvas, delineating in the landscape their bitter counterparts in Europe.

Civilization pressed through a gap at Minnie-Waukon, Spirit Water. It experienced that laceration known to us as the "Spirit Lake Massacre." Immediate causes have been differently recorded by different white sufferers on the one hand, and by the red participants on the other hand, and by writers who were not sufferers, on all hands; but none dispute the consequence as the classic instance in our state of frontier tragedy. It is no less a classic of edge against edge, of race against race, than are the Aftonian gravels classic in their place. Indian and white races, differing in racial origins, in their traditions, in their motives and their ideals, at that time and place visited their penalties upon the homes and against the individuals.

One by one participants in the Spirit Lake Massacre have passed away. Abigail Gardner Sharp, a victim, singularly was spared to be the last. She was fourteen when Inkpaduta's band of Sioux tore her clasp from the bodies of her murdered relatives, dragged her, scantily shod, over the ice of Okoboji into the fastnesses of the Dakotas. They made her and some older neighbor women their beasts of burden. Her body, like that of their other beasts of burden, remained unviolated. She was ransomed but returned to her friends and relatives broken in mind and body. Within a year of her return to civilization she was married. Children came, and death to some of them, and domestic stress and estrangement, and the lone struggle for bread for herself 


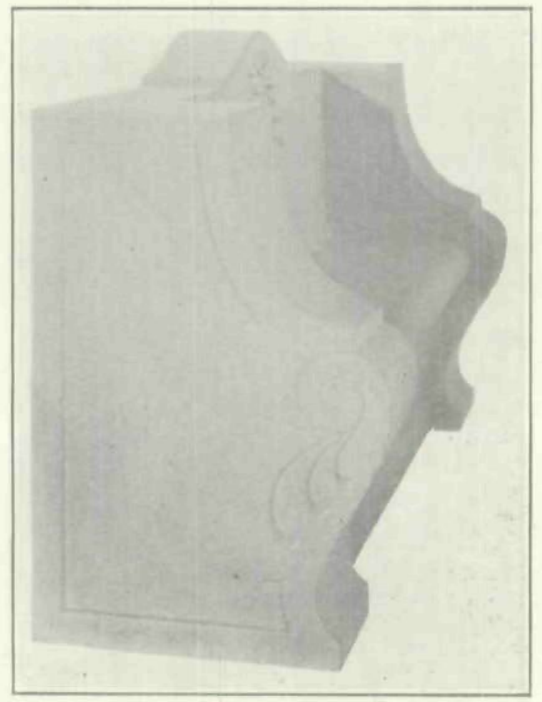

END VIEW OF MEMORIAL TO ABIGAIL GARDNER SHARP

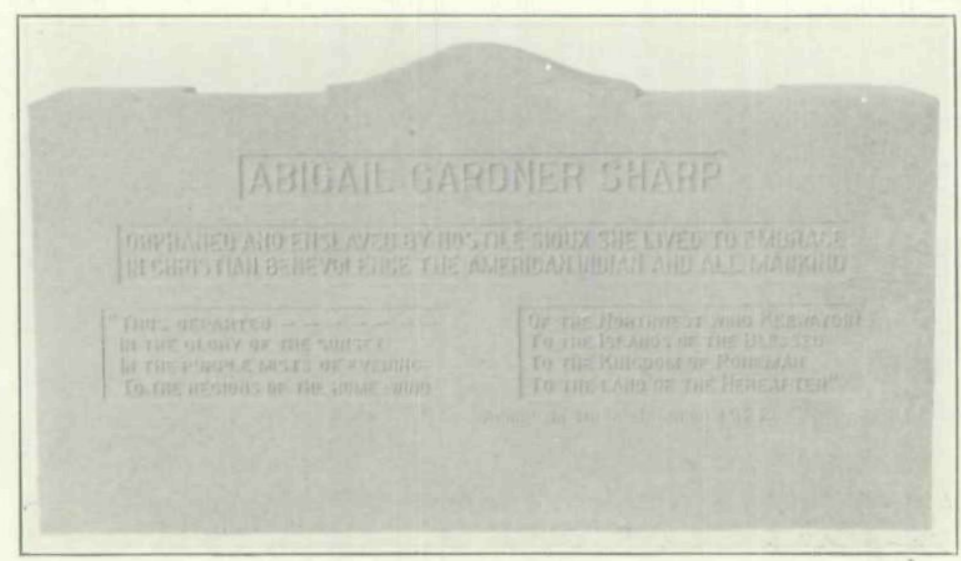

BACK OF MEMORIAL TO ABIGAIL GARDNER SHARP 
and children. The long bitter battle for health and strength was won at last. She bought the cabin where the horror of her life had come,and by charging visitors admission at its door, by vending souvenirs, and through rigid economies and racking labor she gained comfort and competence. She established relations with Deity which sustained and comforted her, and rid her of enmity. She dwelt among the ashes of her life late into its shadows, then was laid away to mingle her dust with that of her kind and kin.

Imagination largely turns through Longfellow to the Indian motif and applies it with intuition to an understanding of Spirit Lake. One almost sings into the song of Hiawatha a counterpart of Mrs. Sharp. We reach not far nor vainly for the feeling that here in this memorial facing the monument our state erected to commemorate the life and death of the pioneers and the cabin of her youth, her shade may sometimes rest and view across the bosom of the lake beyond the "land of the Dakotas," the way beyond "the kingdom of Ponemah" to the Throne of Grace.

Inscribed upon this beautiful memorial erected to her memory by her two grandchildren, Mrs. Fred Wygle and Mr. Albert Sharp, is the following inseriptive sentiment:

\section{ABIGAIL GARDNER SHARP}

Orphaned and Enshaved by Hostme Sroux She Lived to Embrace in Christian Benevolence the American Indian and Alt. Mankind

"Thus departed... .

In the glory of the sunset,

In the purple of the evening,

To the regions of the home-wind,
Of the Northwest wind Keewaydin, To the Islands of the Blessed To the kingdom of Ponemah, To the land of the hereafter."

\section{THE WILL OF ABBIE GARDNER SHARP}

Mrs. Abbie Gardner Sharp, the last survivor of the Spirit Lake Massacre, executed a will which has been admitted to probate and whose provisions in due course of time will be carried out.

Five hundred dollars provided for a monument was wholly inadequate in the belief of her grandehildren, Mrs. Fred Wygle, of Spencer, Iowa, and Mr. Albert Sharp, of Des Moines, who are beneficiaries. They added a most substantial sum whereby there has been erected a structure suitable in mass, material, and design. The environment, unique in history, landscape, accessibility, and use is thereby greatly enhanced in beauty and interest. 
The Curator of the Historical Department enjoyed ten years of intimate friendship with Mrs. Sharp. He was in sympathy with her views on nearly all matters. He had her approval of the sentiments he has had inscribed upon the memorial and he will ever hold with sacred satisfaction the confidential information which supports his sentiments with regard to her public and private affairs.

The Historical Department expects to aid in preserving the historic cabin, if so doing is desired by those named with it in the will, or it will try to do so alone if necessity demands. Shrines need no designation nor dedication. They need but to be respected.

Everyone to whom Mrs. Sharp in her will commends her cabin feels as she felt. Altogether or alone one or others must act in accordance with her wish, which should be the universal wish of Iowa.

The will in its essentials provides:

Section 2. I direct that my body be buried on Lot No. Sixteen of Cass Bay, in the Town of Arnolds Park, in said County, said lot being known as the Gardner family lot, where my father and mother are buried, and I further direct that a suitable monument be erected to mark my grave, costing not to exceed Five Hundred Dollars. And I request Edgar R. Harlan, or his successor in the office of Curator of the Iowa State Historical Department at Des Moines, to superintend the purchase and inscription to be placed on said monument.

Section 5. I hereby nominate and appoint P. O. Bjorenson of Milford, Iowa, executor of this my last will and testament. And in the case of sale as hereinafter provided I will and direct that he have appointed by the Judge of the District Court three disinterested appraisers to fix and determine the value of my certain real property, described as follows, to-wit: Lot "A" of Pillsbury's Point Park, (also known as the "Abbie Gardner Sharp Log Cabin" property), and also Lot Sixteen (16), of Plat of Cass Bay, Dickinson County, Iowa, being original burial ground of the Gardner and Luce families, and I request that Edgar R. Harlan, Curator of the Iowa Historical Department at Des Moines, Iowa, or his successor in office, be one of the appraisers.

My grandchildren, Bonita Wygle, and Albert Sharp, or either of them shall have the privilege of retaining said property, providing they shall maintain same along same lines as has been conducted by me, and to care for same, including the Gardner graves in Lot Sixteen, Plat of Cass Bay, in proper manner with the idea of keeping up its historical significance. In case they do not wish to keep said property, the same 
may be sold by giving the first opportunity of purchase to the Daughters of the American Revolution at the appraised valuation, as fixed and determined by said appraisers, and I hereby authorize my said executor and empower him to make, execute and deliver to the sa:d Daughters of the American Revolution, or any others to whom sold, a good and sufficient conveyance upon the payment having been made; and I further direct that the grantees may have the privilege of paying for said property in installments not longer than five years at not less than $6 \%$ interest. The second privilege of purchase shall be given the Iowa Historical at Des Moines.

I also direct that there shall go with said property to the purchaser and belong with it, all Indian relies, historical collections, furniture and fixtures, (including one bed-stead and bedding therefor with one silk quilt), except books, post eards, and souvenirs said personal property being situated in the certain log cabin on said real estate and not elsewhere. There shall not be included in said sale of the above described property any copy-rights, now owned by me, unless a commission of $10 \%$ on cost price be paid to said grandehildren or their heirs forever for the privilege of publishing the books, photographs etc. copy-righted But the purchaser at said sale may buy said copyrights from said heirs absolutely at such terms as may be agreed upon.

\section{ABSTRACT OF THE MINUTES OF THE STATE BOARD OF CONSERVATION}

\section{JANUARY 10-12, 1921}

Resolutions.-Resolutions were adopted as follows: That as the citizens of Hamburg offer to donate a portion of the initial cost, that the Board recommend to the Executive Council the acquisition of the area near Hamburg when other areas in their order are taken care of and park funds become available; that as the citizens of Fort Atkinson offer to contribute approximately half of the initial cost that the Board recommend to the Executive Council the immediate acquisition of two blocks of ground in the town, including the historic fort and mission buildings.

Areas Considered.-Local citizens appeared in the interest of the following areas and the Board announced to them as follows: Park north of Council Bluffs, that funds are not now available, but when they are, and if local help is given, the Board favors acquisition; Estherville, citizens reported progress on obtaining options; Decorah Ice Caves, citizens said they would assist in purchase price, and they were told the Board is favorable but no funds are now available; Clarksville, citizens state they would contribute part, and were told the Board is favorable but no funds are now available; Clear Lake, citizens offer to contribute, Board told them it is favorable to obtaining the MeIntosh woods, and the citizens say they will try to secure options; Beaman, citizens told 
Copyright of Annals of Iowa is the property of State of Iowa, by \& through the State Historical Society of Iowa and its content may not be copied or emailed to multiple sites or posted to a listserv without the copyright holder's express written permission. However, users may print, download, or email articles for individual use. 